5. Полат Е.С. Новые педагогические и информационные технологии в системе образования. Москва : Просвещение, 2000. 312 с.

6. Что такое Интернет? Информационные и коммуникационные технологии в образовании / А.Г. Кушниренко и др. Информатика и образование. 1998. № 5, 7. С. 56-57.

7. Arny-Macia E. The Role of Technology in Teaching Languages for Specific Purposes Courses. The Modern Language Journal. 1996. P. 89-104.

8. Kern N. Technology-integrated English for Specific Purposes lessons: real-life language, tasks, and tools for professionals. Innovations in learning technologies for English language teaching. 2013. P. 89-115.

9. Yang L.R. Benefits and drawbacks of controlled laboratory studies of second language acquisition. Cambridge University Press. 2001. P. 173-193.

УДК 821.111(94)'34'27

DOI https://doi.org/10.32782/tps2663-4880/2019.12.31

\title{
ВАРІАТИВНИЙ ХАРАКТЕР МОВЛЕННЯ АВСТРАЛІЙЦІВ НА ПРОСОДИЧНОМУ РІВНI
}

\section{VARIATIVE NATURE OF AUSTRALIAN SPEECH AT THE PROSECUTIVE LEVEL}

\author{
Костроміна О.B., \\ orcid.org/0000-0002-6756-7701 \\ кандидат філологічних наук, \\ дочент кафедри англійської мови № 2 \\ Національного університету «Одеська морська академія»
}

Австралійська англійська (AusE), що сполучає у своїй системі ознаки різних регіональних діалектів Великої Британії, етнокультурних діалектів автохтонних мов аборигенів, американського варіанта англійської мови, усе ж таки $€$ самостійно діючим національним варіантом англійської мови з досить широкою варіативністю вживання одиниць усіх рівнів, особливо фонетичного.

Учені по-різному визначають статус AusE. Він розглядається як варіант англійської літературної мови, подібно AmE та BE, як «субстандартний феномен», як територіальний діалект. Австралійські лінгвісти вважають АusЕ самостійною національною мовою. Існує думка, що основна проблема англійської мови в Австралії - це не стільки проблема варіанта або діалекту, скільки проблема акценту, під яким розуміється діалект, основні відмінності якого від мови містяться в царині фонетики, а точніше, у фонемному інвентарі.

Просодичний рівень у дослідженні австралійського варіанта англійської мови є нині маловивченим і найваріативнішим.

Відомо, що в царині інтонації австралійський елемент яскраво забарвлений використанням висхідного тону в стверджувальних реченнях.

Відповідно до поставленої мети вивчення варіативності мелодійного оформлення мовлення носіїв австралійського варіанта англійської мови, в статті досліджуються акустичні характеристики висхідного та висхідно-спадного тонів.

Визначено корпус експериментального дослідження, який становили 78 уривків квазіспонтанного мовлення носіїв австралійської англійської, що визначаються неофіційним характером і невимушеністю. Методом акустичного аналізу визначено основні інтонаційні моделі мовленнєвої поведінки австралійців.

Проведене дослідження дає змогу стверджувати, що найбільш яскравою рисою австралійського акценту є просодія, яка характеризується високою частотністю вживання висхідного тону (ВТ) та висхідно-спадного тону (ВСТ) у нейтрально забарвленому мовлені. Використання цих типів часто пов'язують з інтерференцією американського і британського варіантів мови.

Ключові слова: австралійська англійська, просодичний рівень, висхідний, тон, висхідно-спадний, квазіспонтанне мовлення, частота основного тону (ЧОТ).

Australian English (AusE) which combines in its system features of various regional dialects of Great Britain, American English, ethnocultural dialects of autochthonous languages, on the some time presents an independent national variant of English with a wide variety of units of all language levels usage (phonetic in particular).

Linguists differentiate the status of AusE differently. It is difined as a variant of English literary language, like AmE and BE, as "substandard phenomenon", as territorial dialect. Australian scientists consider AusE as an independent national language. There is an opinion that the main problem of the English language in Australia in the problem of accent, under which they understand a dialect, main differences of which lie in the field of phonetics, more exactly in phonetic inventory. Moreover prosodic level in the investigation of Australian English is the most variable and hasn't yet been studied thoroughly.

It has been previously proved that in the Australian intonation the most frequently used tone is the Rising one in statements. 
Due to the aim of the investigation the study of variable character of melodic component in the speech of Australian English representatives, acoustic characteristics of Rising and Rising-Falling terminal tones has been studied in the given article.

The material of investigation comprises 78 fragments of quazispontaneous speech of Australian English informants which are informal and constraint in their character. Main intonational models of Australian's behavior have been studied by acoustic method.

Thus, the conducted research allows to state that the brightest feature of Australian English Accent is prosody which is characterized by high frequency of Rising and Rising-Falling tones usage in neutral utterances. The usage of these two tones is often connected with the interference of British and American English.

Key words: Australian English, prosodic level, Rising tone, Rising-Falling tone, quazispontaneous speech, frequency.

Постановка проблеми. Зацікавленість вивченням австралійського варіанта англійської мови (далі - AusE) і загалом національних варіантів англійської мови має низку причин. 3 одного боку, це всесвітня культурна «експансія» англійської мови, яка сприяє появі маловідомих iï варіантів, з іншого боку, руйнування колишніх стереотипів (відмова від виняткової переваги викладання норми RP у навчальних закладах Європи, що донедавна було типовим) [1]. Увага до AusE у статті викликана як суто теоретичними (маловивченість, багатогранний характер, проблема World Englishes тощо), так і практичними (вивчення нового національного варіанта, розвиток відносин між сучасною Україною й Австралією тощо) факторами.

Аналіз останніх досліджень і публікацій. Розвиваючись в умовах географічної й культурної ізоляції, під впливом екстралінгвальних факторів - особливостей навколишньої природи та способу життя, контактних мов, англійська мова в Австралії набула певних особливостей. Вони дають змогу визначити іï статус як такого національного варіанта англійської мови, що розвивається власним шляхом, самостійно функціонує й має досить широку варіативність уживання одиниць усіх рівнів (насамперед лексичного та фонетичного). AusE не є другорядною щодо англійської мови, як це властиво територіальним діалектам, вона не обмежена сферою побутового усного мовлення. Вона використовується в державних та освітніх установах, $\epsilon$ мовою засобів масової інформації й художньої літератури.

Австралія - мультилінгвальна країна. Тут розмовляють різними мовами (для $80 \%$ населення англійська $\epsilon$ рідною мовою; інші $20 \%$ - білінгви або трилінгви, для яких англійська $\epsilon$ другою (третьою) мовою, тобто емігранти 3 Німеччини, Італії, Греції, арабських країн, Китаю). Незважаючи на те що вимова мешканців Австралії може бути маркована континентальним акцентом, їхнє мовлення, безперечно, залишається австралійським [15].

Сучасна мовна політика Австралії забезпечує державну підтримку не тільки англійській мові як домінуючій за кількістю мовців і за тією соціаль- ною роллю, яку вона (англійська мова) виконує, а й усім іншим мовам, розповсюдженим на території країни [5; 14].

Відстань та ізольованість від інших країн і континентів - два головні фактори, що впливають на життя й розвиток AusE.

Учені по-різному визначають статус AusE. Він розглядається як варіант англійської літературної мови, подібно AmE та ВE [7], як «субстандартний феномен», як територіальний діалект [3, с. 6]. Р. Іглсон [12], Г. Гай [14] уважають AusE самостійною національною мовою. Існує думка (M. Barnard), що основна проблема англійської мови в Австралії - це не стільки проблема варіанта або діалекту, скільки проблема акценту [8, с. 66-71], під яким розуміється діалект, основні відмінності якого від мови містяться в царині фонетики, а точніше, у фонемному інвентарі. Проте це питання в сучасній англістиці недостатньо висвітлене.

Просодичний рівень у дослідженні австралійського варіанта англійської мови є нині маловивченим і найваріативнішим.

Відомо, що в царині інтонації австралійський елемент яскраво забарвлений використанням висхідного тону у стверджувальних реченнях.

Дуже цікавим $є$ питання акцентології в AusE. Тут також наявна певна варіативність. У деяких словах спостерігається зсув наголосу, відмінний від RP і в деяких випадках від AmE. Наприклад: int'ricacy, 'anecdote, 'realise тощо. Акцентна структура багатьох слів в AusE відбиває вплив $\mathrm{AmE}$ (прямування до спрощення).

Питання про просодичну варіативність мовлення в Австралії залишається невирішеним і вимагає подальшого вивчення $[9 ; 16 ; 11]$. Однак австралійські вчені XXI століття одноголосно зізнаються, що етнокультурна й регіональна варіативність у майбутньому збільшаться в ході більш глибоких досліджень у цій галузі [10; 11].

$\mathrm{Y}$ наш час великий вплив на AusE має американський варіант англійської мови [16], що відбивається на всіх рівнях мовної системи.

Постановка завдання. Метою пропонованого дослідження $є$ визначення варіативного характеру мелодійного оформлення мовлення австралійців. 
Матеріалом дослідження послугували 78 фрагментів квазіспонтанного мовлення носіїв австралійського варіанта англійської мови, вилучені 3 програми «Grand Designes Australia», яка транслюється на телевізійному каналі «The Lifestyle Channel».

Виклад основного матеріалу. Відповідно до поставленої мети вивчення варіативності мелодійного оформлення мовлення носіїв австралійського варіанта англійської мови, у статті досліджуються акустичні характеристики висхідного та висхідно-спадного тонів, які, як показали попередні дослідження О.В. Костроміної, є найбільш частотними в GenAus (General Australian). В аналізі також ураховувалися висновки дослідників щодо ролі інтенсивності й тривалості, отримані шляхом спостереження над сприйняттям інтонації в Англії та США [6] і в результаті спеціальних експериментів зі створення ефекту виділеності [13].

Необхідність установлення характерних рис висхідного та висхідно-спадного тонів в австралійському варіанті англійської мови зумовила вивчення таких акустичних показників частоти основного тону (далі - ЧОТ), тривалості й інтенсивності:

ЧОТ: середні значення мінімумів і максимумів ЧОТ (Гц), середній інтервал висхідного руху ЧОТ (отн. ед.), середній інтервал спадного руху ЧОТ (отн. ед.), співвідношення інтервалів висхідного й спадного руху ЧОТ.

Тривалість: середня тривалість висхідного руху (мс), середня тривалість спадного руху (мс), співвідношення тривалості висхідного й спадного руху.

Інтенсивність: локалізація максимуму інтенсивності у висхідній або спадній частині.

Важливою частиною вивчення варіативності конфігурацій висхідного та висхідно-спадного тонів є комбінаторика, тобто комбінація показників ЧОТ, інтенсивності й тривалості.

Частотність висхідного тону (далі - ВТ) у досліджуваному копусі становила $35,7 \%$. Iз 78 досліджених фрагментів 25 відібрані для акустичного аналізу.

Згідно $з$ отриманими результатами, частотність уживання висхідного тону знижується відповідно до віку мовця. У мовленні молодого покоління ВТ зустрічається в 17,4\% випадків; у мовленні середнього покоління це значення становить 14,3\%, у мовленні представників старшого покоління ВТ становить усього 4\%. Ці результати повністю суперечать більш раннім дослідженням автора [4]. Гендерний фактор підтвердив тенденцію про більш частотне вживання ВТ в жіночому мовленні, ніж у чоловічому.

Якщо зіставити дистрибуцію термінальних тонів серед двох гендерних груп дикторів молодого покоління, то в мовленні чоловіків відсоток використання ВТ - 7\%, а в мовленні жінок - 10,4\%.

Параметри ЧОТ і тривалості у ВТ розглядалися на підставі таких показників:

ЧOT: середні значення мінімуму й максимуму ЧОТ (Гц), середній інтервал висхідного руху ЧОТ (пт).

Тривалість: середня тривалість наголошеного складу (мс), середня тривалість наголошеного й занаголошеного складів у багатоскладових словах (мс), співвідношення тривалості наголошеного складу до тривалості занаголошеного складу в багатоскладових словах.

Середнє значення мінімуму ЧОТ становило 205 Гц, а середнє значення максимуму - 174 Гц.

Середній інтервал висхідного руху ЧОТ становив 3,8 відн. од.

Якщо порівняти середні значення мінімуму й максимуму ЧОТ у ВТ з аналогічними параметрами висхідного відрізка руху ЧОТ у складному висхідно-спадному тоні (далі - ВСТ), то мінімум ЧОТ при ВСТ становить 194 Гц, а максимум 167 Гц.

Отже, максимум ЧОТ у простому ВТ знаходиться трохи вище за середній рівень, ніж у складному ВСТ. Значення середнього інтервалу висхідного руху, однак, нижче в простому ВТ, ніж у складному ВСТ, де воно становить 2,8 пт.

Середня тривалість наголошеного складу у ВТ становила $411 \mathrm{mc.}$

У багатоскладових словах тривалість занаголошеного складу в більшості випадків перевищує тривалість наголошеного. У $10 \%$ тривалість наголошеного складу перевищувала тривалість занаголошеного. У 2\% випадків ці показники збігалися (таблиця 1).

Результати аналізу висхідно-спадного тону свідчать про те, що в структурі ВСТ рівень початку висхідного тону ЧОТ розташовано на 17 Гц вище за рівень спадного завершення тону: середньомінімальні значення ЧОТ становлять 126 Гц і 152 Гц відповідно. Середньомаксимальний рівень ЧОТ 134 Гц. Отримані результати наведено на рисунку 1.

Зіставлення інтервалів ЧОТ у висхідній і спадній частинах ВСТ також свідчить про більш широкий діапазон спадного руху ЧОТ: середній інтервал висхідного руху ЧОТ становив 1,5 відн. од., а середній інтервал спадного руху ЧОТ 1,8 відн. од. Більший інтервал спадного руху тону домінує, у решті випадків зафіксовано або під- 
Середня тривалість наголошеного і занаголошеного складів, співвідношення їх тривалості в багатоскладових словах

\begin{tabular}{|r|c|c|c|c|}
\hline \multirow{2}{*}{ Тип складу } & \multirow{2}{*}{ Частотність, \% } & \multicolumn{2}{|c|}{ Середня тривалість (мс) } & Співвідношення \\
\cline { 3 - 5 } & триволошений склад & занаголошений склад & 0,4 \\
\hline $\begin{array}{l}\text { Наголошений }< \\
\text { занаголошений }\end{array}$ & 78 & 277 & 318 & 1,2 \\
\hline $\begin{array}{l}\text { Наголошений }> \\
\text { занаголошений }\end{array}$ & 12 & 268 & 171 & 0,9 \\
\hline $\begin{array}{l}\text { Наголошений }= \\
\text { занаголошений }\end{array}$ & 10 & \multicolumn{2}{|c|}{179} & \\
\hline
\end{tabular}

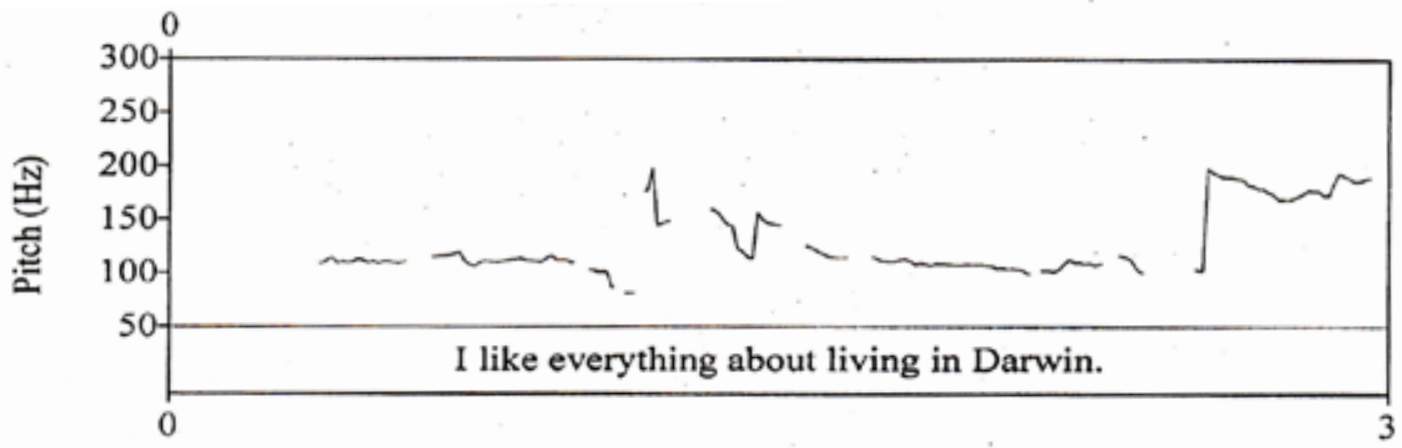

Time (s)

Рис. 1. Інтонограма фрази «I like everything about living in Darwin» (чоловік, середньої вікової групи)

вищення інтервалу висхідного руху, або рівність інтервалів висхідного і спадного руху тону.

У групі молодого покоління, де спадний рух тону менш значний, середній інтервал підйому становив 1,6 відн. од., середній інтервал падіння дорівнює 1,3 відн. од. У разі домінування висхідного тону середній інтервал підйому становив 1,7 відн. од., а середній інтервал спадного тону $-1,8$ відн. од. За приблизної рівності інтервалів середнє значення як підйому, так і падіння становило 1,65 відн. од.

Вивчене співвідношення дає змогу стверджувати, що в середньому інтервал спадного руху тону в групі молодого покоління нижчий за інтервал висхідного руху $(1: 2)$. Співвідношення інтервалу підйому до інтервалу падіння в групі представників середнього покоління становило 1,8:1,3. У групі представників старшого покоління співвідношення інтервалів 1,1:1,1 (таблиця 2).

Дані аналізу щодо тривалості показують, що середня тривалість висхідної частини тону менша за тривалість спадного руху тону: середня тривалість підйому становила $171 \mathrm{mc}$, а середня тривалість падіння - 294 мс.

У $90 \%$ випадків тривалість підйому була нижча за тривалість падіння; у 8\% - тривалість підйому була вища за тривалість падіння. У $2 \%$ випадків величини тривалості підйому і тривалості падіння різнилися незначно.

У групі, де тривалість спадного руху тону перевищувала тривалість висхідного руху, середня тривалість підйому становила 159 мс, а середня тривалість падіння дорівнювала 301 мс. У зворотному співвідношенні середня тривалість підйому становила 239 мс, а середня тривалість падіння - 198 мс. За рівної тривалості середнє значення як підйому, так і падіння становило близько 274 мс.

Отже, отримані під час дослідження результати свідчать про те, що середня тривалість спадного руху тону удвічі перевищує середню тривалість висхідного руху (1:2).

\section{Середні значення інтервалів висхідного і спадного руху ЧОТ і їх співвідношення}

$$
\text { в трьох групах (у відн. од.) }
$$

\begin{tabular}{|l|c|c|c|c|}
\hline \multirow{2}{*}{\multicolumn{1}{|c|}{ Група }} & \multirow{2}{*}{ Частотність (y \%) } & \multicolumn{2}{c|}{ Середній інтервал, відн. од. } & \multirow{2}{*}{$\begin{array}{c}\text { Співвідношення } \\
\text { інтервалів }\end{array}$} \\
\cline { 3 - 4 } & & підйом & падіння & 1,1 \\
\hline Молоде покоління & 65 & 1,65 & 1,6 & 1,45 \\
\hline Середнє покоління & 18 & 1,8 & 1,3 & 1,1 \\
\hline Старше покоління & 17 & 1,1 & 1,1 & \\
\hline
\end{tabular}


Наступним етапом дослідження було виділення варіантів контуру висхідно-спадного тону залежно від положення максимуму ЧОТ щодо наголошеного складу. Аналіз показав, що найбільш частотні пікові показники ЧОТ припадають на перший наголошений склад (більше ніж 57\%), на ядровий склад (друга група) припадає 34\% і 9\% припадають на заядрові склади (третя група). До першої групи, як правило, належать слова, у яких наголос падає на перший склад, тобто «пік» ЧОТ розташовується ближче до початку слова. Друга група, де відрізки висхідного і спадного руху ЧОТ багато в чому симетричні, містить велику кількість багатоскладних слів. Третя група при цьому містить різні за морфологічним складом слова й має невелику кількість прикладів для виявлення закономірності.

Під час аналізу сполучення ЧОТ та інтенсивності напрям руху ЧОТ та інтенсивність збіглися в $69 \%$ випадків, а різноспрямований рух - у $31 \%$ від загальної кількості прикладів уживання ВСТ.

Подібна розбіжність руху, як уже зазначено автором статті, може бути компенсаційним явищем у тих випадках, коли наголос слабко виражений лише за допомогою ЧОТ, інтенсивність допомагає виділити наголошений склад у потоці мовлення. Однак у деяких випадках інтенсивність має кілька «піків», які можуть як збігатися, так і не збігатися 3 максимальними показниками ЧОТ, а також можуть як впливати, так і не впливати на загальне сприйняття тону. Також максимуми інтенсивності залежать і від звукового складу слова, а саме від наявності в ньому глухих (сильних) приголосних.

Сполучення ЧОТ і тривалості в досліджуваному корпусі показало, що в більшості випадків (67\%) тривалість спадного руху перевищує тривалість висхідного руху ЧОТ; у 20\% випадків тривалість підйому перевищувала тривалість падіння; в 13\% - обидва відрізки приблизно збігалися за тривалістю.

У досліджуваному матеріалі зафіксовано приклади згладженого контуру ЧОТ, як, наприклад, у мовленні представників молодого 1 середнього покоління (рисунки 2, 3).

Висновки. Проведене дослідження дає змогу стверджувати, що найбільш яскравою рисою

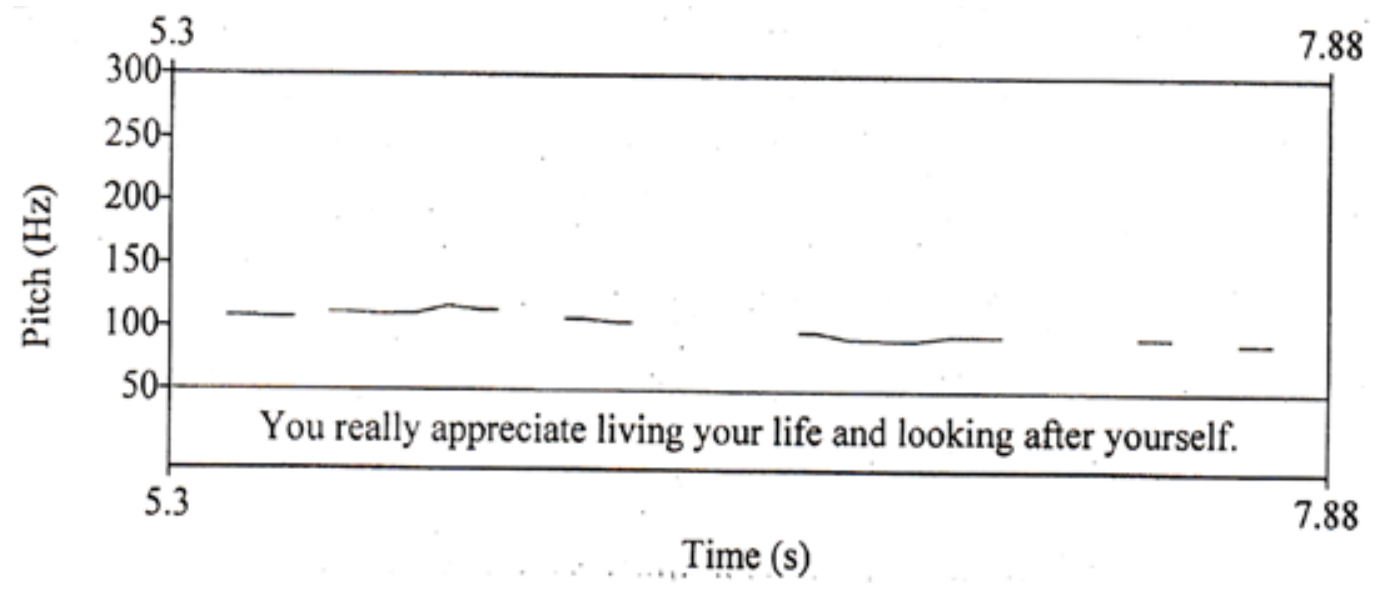

Рис. 2. Інтонограма фрази «You really appreciale living your life and looking after yourself» (у мовленні представника середнього покоління)

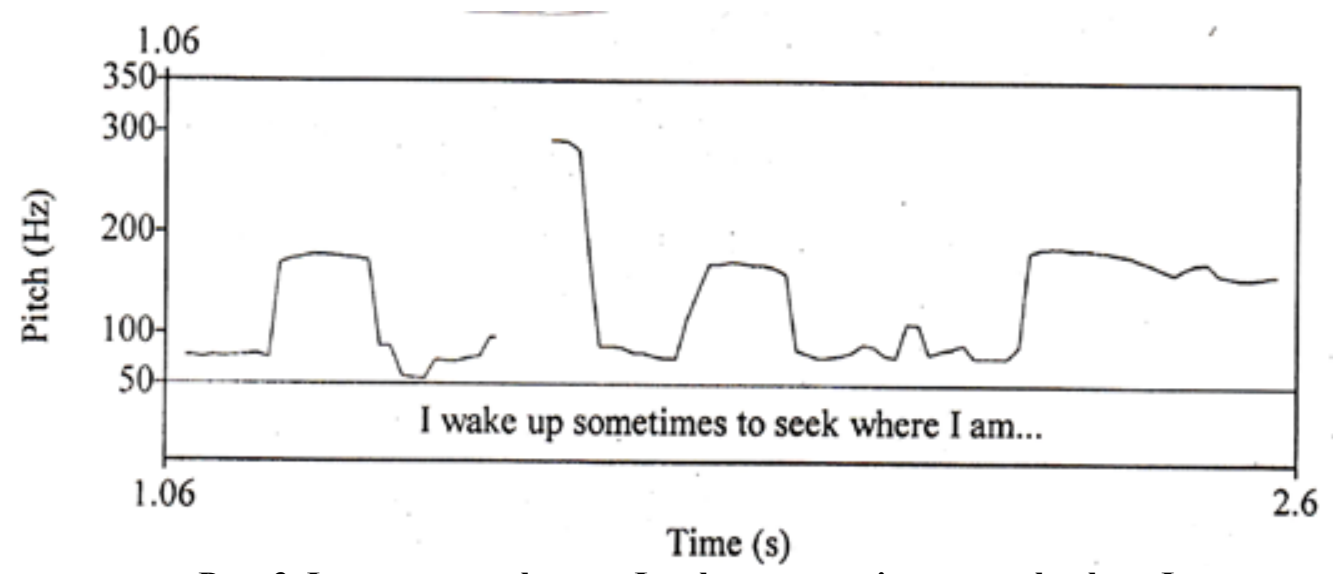

Рис. 3. Інтонограма фрази «I wake up sometimes to seek where I am...» (у мовленні представника молодого покоління) 
австралійського акценту є просодія, яка характеризується високою частотністю вживання ВТ та ВСТ в нейтрально забарвленому мовлені. Використання цих типів часто пов'язують з інтерференцією американського й британського варіантів мови.

Висхідно-спадний термінальний тон $є$ третім за вживаністю тоном, поступаючись висхідному та рівному тонам.
Найбільш характерними акустичними рисами складного ВСТ виявився високий рівень початку висхідного руху ЧОТ порівняно з рівнем завершення спадного руху тону; велика інтенсивність і тривалість спадного руху тону. До особливостей ВСТ можна зарахувати також плавний характер руху ЧОТ. Проте така модель менш частотна в мовленні австралійців.

\section{СПИСОК ВИКОРИСТАНИХ ДЖЕРЕЛ:}

1. Абызов А.А. Фонетические характеристики английской компрессированной речи (на материале канадского варианта английского языка) : дисс. ... канд. филол. наук. Иваново, 2005. 242 с.

2. Бродович О.И. Диалектная вариативность английского языка: аспекты теории. Ленинград : ЛГУ, 1988. $193 \mathrm{c}$.

3. Егорова О.А. Интонационные особенности женской разговорной речи (на материале австралийского варианта английского языка) : авторефр. дисс. ... канд. филол. наук : 10.02.04. Иваново : ИвГУ, 2008. 22 с.

4. Костроміна О.В. Соціофонетичні особливості австралійського варіанта англійської мови (експериментально-фонетичне дослідження на матеріалі спонтанного мовлення) : автореф. дис. ... канд. філол. наук : 10.02.04. Одеса, 2015. 19 с.

5. Ощепкова В.В. Язык и культура Великобритании, США, Канады, Австралии, Новой Зеландии. Москва Санкт-Петербург : ГЛОССА/КАРО, 2006. 336 с.

6. Социолингвистическая вариативность национального языка как целостной структуры / А.Д. Петренко и др. Севастополь : Украинский морской институт, 2009. 182 с.

7. Шахбагова Д.А. Фонетическая система английского языка в диахронии и синхронии (на материале британского, американского, австралийского, канадского вариантов английского языка). Москва : Фоллис, 1992. $283 \mathrm{c}$.

8. Barnard M. A History of Australia. Sydney : Currawong, 1962. 186 p.

9. Bradley D. Regional Dialects in Australian English Phonology. Australian English: The Language of a New Society II. St. Lucia, Queensland: University of Queensland Press, 1989. P. 260-270.

10. Proceedings of the 10th Australian International Conference on Speech Science and Technology, December, Sydney / S. Cassidy, F. Cox, R. Mannell, S. Palethoipe. Sydney, Australia : Macquarie University, 2004. P. 35-42.

11. Cox F., Palethorpe S. An Illustration of the 1PA: Australian English. Journal of the International Phonetic Association. 2007. № 37. P. 341-350.

12. Eagleson, R.D. The Evidence for the Existence of Social Dialects in Australian English. Australia Tasks: Essays on the Sociology of Australian Immigrant and Aboriginal languages / Clyne M.G. (ed.). Canberra : Australian University Press, 1967. P. 7-27.

13. Grabe E., Kochanski G., Coleman J. Quantitative Modelling of Intonational Variation. Proceedings of Speech Analysis, Synthesis and Recognition in Technology, Linguistics and Medicine. Poland, 2005. P. 45-57.

14. Guy G.R. Australia. English Around the World: Sociolinguistic Perspectives / J. Cheshire (ed.). Cambridge : CUP, 1991. $213 p$.

15. Johnson K. \& J.W. Mullennix (eds.). Speech Perception without Speaker Normalization: An Exemplar Model

I I Talker Variability in Speech Processing. San Diego : Academic Press, 1997. P. 145-165.

16. Lehiste I. Suprasegmentals. Cambridge, MA : MIT Press, 1970. $196 \mathrm{p}$.

17. McArthur T. Oxford Guide to World English. Oxford : OUP, 2003. 501 p. 